\title{
Раздел II
}

\section{Итоги XXVII конкурса в МГИМО}

В Ибероамериканском центре МГИМО МИД России в рамках Российской ассоциации международных исследований (РАМИ) и при поддержке журнала «Латинская Америка» состоялся традиционный ежегодный (2019 г.) конкурс студенческих работ (председатель конкурсной комиссии - проф. Л. С. Окунева).

Представляем его результаты:

\section{1 место}

Васильев А. Внутренние и внешние факторы развития кризиса в Боливарианской Республике Венесуэла в 2014-2019 гг.

Михайлович А. Особенности бразильско-американских отношений в начале XXI в.

Семенов С. Участие стран Латинской Америки в процессах нераспространения ядерного оружия и разоружения.

Деточка М. Эволюция российско-кубинских отношений на современном этапе: формирование новой модели сотрудничества.

Виноградова Е. Отношения стран Латинской Америки с государствами ЕС на современном этапе.

\section{2 место}

Коновалов И. Президентская дипломатия в странах Латинской Америки: эволюция и современность.

Литова Д. Внешнеполитические аспекты сотрудничества Бразилии и Китая.

Чеботаренко Д. Экспансия Китая в странах Латинской Америки и Карибского бассейна в XXI в.: результаты и перспективы.

Клещенко К. Индейский фактор во внешней политике Боливии в период правления Эво Моралеса (2006-2019 гг.).

Ростов В. Роль левых партий в общественно-политической жизни Испании на рубеже XXXXI вв.

\section{3 место}

Слабодчикова М. Роль Испании в НАТО и ЕС в конце XX-начале XXI вв.

Глухов И. Национальная безопасность Бразилии: особенности доктрины и роль в структуре региональной безопасности Латинской Америки.

Дорофеева А. Конфликтный характер американо-венесуэльских отношений в 2013-2019 гг.

Молочкова Н. Современные тренды развития интеграционных процессов в Латинской Америке. 


\section{Почетных дипломов Ибероамериканского центра удостоены:}

Абенова А. Политический портрет Фиделя Кастро.

Агейчева Э. Правление ДилмыРусеф в зеркале бразильских и зарубежных СМИ.

Андрющенко Г. Эволюция внутреннего гражданского конфликта в Колумбии на современном этапе.

Безменов П. Военно-техническое сотрудничество между Бразилией и странами Западной Европы (2008-2018 гг.).

Божков Е. Правый поворот в Бразилии: тогда и сейчас.

Горланова Е. Правительство Народного единства в Чили. Причины и движущие силы политической дестабилизации.

Кремзер А. Правление Фернанду Коллора ди Мелу и его итоги.

Переверзева А. Политический портрет Уго Чавеса.

Саввин А. Эволюция политических процессов в Чили в 1950-1960-е годы. Истоки Чилийской революции.

Самойлова Е. Особенности трансформации внешнеполитического курса Бразилии во втором десятилетии XXI в.

Суворов А. Политический портрет Эво Моралеса.

Харченко В. Формирование элементов новой политической системы в ходе Кубинской революции.

Конкурсная комиссия отмечает вклад и выражает благодарность научным руководителям лауреатов - профессорам Н. Е. Аникеевой, Е. М. Астахову, Б. Ф. Мартынову, Л. С. Окуневой, В. П. Судареву, доцентам И. А. Ахтамзяну, А. В. Крыжановскому, И. В. Попову. 